\title{
Phosphorus release kinetics in a soil amended with biosolids and vermicompost
}

\author{
M. Islas-Espinoza $\cdot$ L. Solís-Mejía $\cdot$ M. V. Esteller
}

Received: 26 June 2012/ Accepted: 8 May 2013/Published online: 27 June 2013

(C) Springer-Verlag Berlin Heidelberg 2013

\begin{abstract}
Wastewater biosolids are large potential sources of macronutrients for agriculture, conservation and restoration of soils; there are, however, few studies on phosphorus (P) release in soils amended with biosolids. Biosolids and vermicomposted biosolids were tested in concentrations (5-30 g amendment $\mathrm{kg}^{-1}$ soil) equivalent to $18-100 \mathrm{Mg}$ $\mathrm{ha}^{-1}$. Desorption of $\mathrm{P}$ was determined by successive extractions for 65 days. Soil $\mathrm{P}$ was low, and biosolid and vermicompost addition released 8 and 6 times more $P$, respectively, than soil alone. To describe the release of P, zero-, first- and second-order equations, simple Elovich and power functions and the parabolic diffusion law were compared based on their coefficient of determination $\left(r^{2}\right)$ and standard error (SE). In all treatments, the power function and especially the parabolic diffusion law were the best fit, with 0.898-0.996 $r^{2}$ and 0.022-0.732 SE. The general behavior of the kinetic parameters mostly depended on the amendment doses. Eutrophication posited to start beyond $16 \mathrm{mg} \mathrm{P} \mathrm{kg}^{-1}$ soil was more likely allayed by a maximum vermicompost dose of $50 \mathrm{Mg} \mathrm{ha}^{-1}$, higher than the $36 \mathrm{Mg} \mathrm{ha}^{-1}$ maximum biosolid dose. The higher vermicompost $\mathrm{P}$ addition and lower $\mathrm{P}$ release could favor gradual and longer-term $\mathrm{P}$ absorption by plants and may reduce leaching or runoff $\mathrm{P}$ losses.
\end{abstract}

Keywords Phosphorus · Biosolids - Vermicompost · Release kinetics · Soil

Electronic supplementary material The online version of this article (doi:10.1007/s12665-013-2549-y) contains supplementary material, which is available to authorized users.

M. Islas-Espinoza $(\bowtie) \cdot$ L. Solís-Mejía $\cdot$ M. V. Esteller Centro Interamericano de Recursos del Agua (CIRA),

Universidad Autónoma del Estado de México,

Cerro Coatepec, s/n, C.U., 50130 Toluca, Mexico

e-mail: marinaislas@ymail.com

\section{Introduction}

Wastewater treatments produce biosolids (microbially digested sludge) which, under certain conditions, can add organic matter to soils (Franco-Hernández et al. 2003; Rostagno and Sosebee 2001), as well as P and other macro and micronutrients (Maguire et al. 2001; SolísMejía et al. 2012). Bioavailability of these nutrients to plants usually occurs through mineralization of organic matter present in biosolids, a process facilitated and accelerated by earthworms (Cardoso-Vigueros and Ramírez-Camperos 2002). The earthworms' metabolism and interaction with microorganisms convert organic waste into humus and other nutrients that induce plant growth (Capistrán et al. 2004).

As the application rate of biosolids on agricultural land is often based on nitrogen content, the significant amounts of $\mathrm{P}$ in biosolids (Korboulewsky et al. 2002; Penn and Sims 2002) can exceed the needs of plants and soil microorganisms; water runoff or infiltration can cause eutrophication of surface water and groundwater pollution (Esteller et al. 2009; Penn and Sims 2002; Shober and Sims 2003).

In soil amended with animal manure and sewage sludge, $\mathrm{P}$ release can be described by a power function (Siddique and Robinson 2004). P release kinetics in calcareous soils, amended and unamended with sewage sludge, fit firstorder, Elovich, power and parabolic diffusion equations adequately (Hosseinpur and Pashamokhtari 2008). In other calcareous soils, amended with composted manure and pistachio, $\mathrm{P}$ release kinetics is best described by Elovich and power functions (Fekri et al. 2011).

However, no reports have yet described $\mathrm{P}$ release in waste-amended sandy clay loam soils. Tropical soils subject to heavy seasonal rains have seldom been studied 
(Quesada et al. 2011; Schad et al. 2001). Mexican sandy clay loam soils (Améndola et al. 2005) are often in intensive agriculture and P-deficient. This type of soil has high porosity and favors water infiltration, which facilitates penetration by plant roots (FAO 2006) but also could promote $\mathrm{P}$ lixiviation if excess nutrients are supplied. Accordingly, the objectives of this research were firstly to measure $\mathrm{P}$ release in a sandy clay loam soil at different doses of organic waste amendment (biosolid and vermicomposted biosolid); and secondly, to compare different $\mathrm{P}$ release kinetics models in the treatments and soil control.

\section{Methods}

Soil sampling and analysis

Eight samples were collected randomly from the Ap horizon $(0-30 \mathrm{~cm})$ of agricultural land in Xonacatlán $\left(19^{\circ} 24^{\prime} \mathrm{N}\right.$, $99^{\circ} 32^{\prime} \mathrm{W}$, State of Mexico, Mexico). Samples of $1.5 \mathrm{~kg}$ each, were mixed in a composite sample subsequently air dried and sieved $(<2 \mathrm{~mm})$. Particle size was determined (Bouyoucos 1962), as well as bulk density (Jaramillo 2002), electrical conductivity in a 1:2 soil: water suspension with a conductivity meter (Rhoades 1996) and $\mathrm{pH}$ in the same suspension with a potentiometer (Thomas 1996). Also analyzed were available phosphorus (Olsen and Sommers 1982), organic matter content by the wet oxidation method (Primo and Carrasco 1987), total organic carbon, total Kjeldahl nitrogen (Cardoso-Vigueros and Ramírez-Camperos 2002). Available nitrogen was extracted with $\mathrm{KCl}$ (Mariani et al. 2007; Siddique and Robinson 2004) and cation exchange capacity with $\mathrm{BaCl}_{2}$-triethanolamine (Primo and Carrasco 1987). The same techniques to determine cation exchange capacity, $\mathrm{C}, \mathrm{P}$, and $\mathrm{N}$ were used in soil, biosolids and vermicompost.

\section{Biosolids sampling and analysis}

Biosolids were obtained from the North Toluca domestic wastewater treatment plant (Mexico State). The sludge is produced during wastewater treatment consisting of thickening, aerobic digestion and drying on filters (Gobierno del Estado de México 1996). Three 20-kg samples of biosolids were collected in 1 day, from which two $1-\mathrm{kg}$ subsamples were mixed in a composite sample which was air dried, sieved ( $<2 \mathrm{~mm})$ and analyzed for physicochemical characteristics. The $\mathrm{pH}$ was measured in a 1:5 water: biosolid solution, as was electrical conductivity (NMX-FF109-SCFI-2007). The organic matter was estimated by ignition and total organic carbon was obtained assuming that the organic $\mathrm{C}$ corresponds to $58 \%$ of the total organic matter (Primo and Carrasco 1987).

Vermicompost processing, sampling and analysis

The biosolid previously described was also used as vermicompost substrate. However, fresh biosolid as the sole substrate for the earthworm Eisenia fetida led to high earthworm mortality, possibly due to the presence of heavy metals in the domestic wastewater, as well as possible excess moisture (Dayananda et al. 2008; Mahimairaja 2000). Metal concentrations in biosolids from the wastewater treatment plant under study were 1,656 and $247 \mathrm{mg} \mathrm{kg}^{-1}$ ( $\mathrm{Zn}$ and $\mathrm{Cu}$, respectively, Gomez-Beltran 2009) which were 62 and $110 \%$ of earthworm median lethal concentration $\left(\mathrm{LC}_{50}\right)$; furthermore, these concentrations did not take into account synergistic lethal effects among these and other, less concentrated metals (Song et al. 2002). A 90:10 biosolid: composted manure mixture in three containers allowing for leachate evacuation ensured earthworm survival (Solís-Mejía et al. 2012). The amount of substrate in each container was approximately $0.8 \mathrm{~kg}$ dry matter. During vermicomposting, moisture was monitored with a soil hydrometer and kept between 70 and $80 \%$ (Cardoso-Vigueros and Ramírez-Camperos 2002) by adding distilled water. Temperature was kept at $15 \pm 2{ }^{\circ} \mathrm{C}$.

Vermicomposting consisted in adding 50 adult earthworms in each container (Contreras-Ramos et al. 2005; Natchimuthu and Thilagavathy 2009), equivalent to $40 \mathrm{~g}$ of earthworm biomass. Vermicomposting went on for 2 months. A sample of approximately $200 \mathrm{~g}$ from each container was mixed to form a composite sample, which was air dried, ground and sieved $(<2 \mathrm{~mm})$. Additional details on the vermicompost are provided elsewhere (SolísMejía et al. 2012).

$\mathrm{P}$ release kinetics

The fresh biosolid was mixed with $100 \mathrm{~g}$ of soil in proportions equivalent to 0 (control), 18, 36, 50, 80 and $100 \mathrm{Mg} \mathrm{ha}^{-1}$ biosolid, considering 30-cm-thick topsoil and $1.1 \mathrm{~g} \mathrm{~cm}^{-3}$ soil bulk density. The same procedure was carried out with vermicompost. The mixtures were incubated at $29 \pm 2{ }^{\circ} \mathrm{C}$ for 10 days and moisture content was maintained at $100 \%$ of the field capacity (Siddique and Robinson 2004). At the end of incubation, the mixtures were dried at room temperature (Vaca-Paulín et al. 2006). The samples were subjected to a successive extraction process using $0.01 \mathrm{M} \mathrm{KCl}$ solution (Lair et al. 2009) for which three $5-\mathrm{g}$ replicates were added $25 \mathrm{~mL}$ of $\mathrm{KCl}$ solution and agitated for $1 \mathrm{~h}$ on an orbital shaker at $180 \mathrm{rpm}$ and then placed in an incubator at $25 \pm 1{ }^{\circ} \mathrm{C}$. 
After $23 \mathrm{~h}$, the samples were removed from the incubator, stirred for $1 \mathrm{~h}$ and centrifuged for $15 \mathrm{~min}$ at 3,000 rpm (Shariatmadari et al. 2006) to precipitate the solid part of the sample and so avoid particles in the subsequent colorimetry analysis. The supernatants were decanted and filtered using Whatman filter paper No. 42, and P was analyzed by colorimetry (Murphy and Riley 1962). The centrifuged and filtered samples were again added $25 \mathrm{~mL}$ of $0.01 \mathrm{M} \mathrm{KCl}$ solution and placed in the incubator for the following extractions after 2, 4, 7, 11, 15, 20, 25, 30, 37, 44, 51, 58 and 65 days (Hosseinpur and Pashamokhtari 2008).

\section{Data analysis}

The concentration of $\mathrm{P}$ (mean of triplicates) was plotted against time. The $\mathrm{P}$ release kinetics were fitted using zero-, first- and second-order equations, the simple Elovich function, the power function and the parabolic diffusion law (Table 1). Curve fitting used Microsoft Excel 2007 and linear regressions used SPSS version 19. The resulting equations were compared based on $r^{2}$ and standard errors of the estimates $\mathrm{SE}=\left[\left(\Sigma\left(P_{\mathrm{t}}-P_{0}\right)^{2}\right) /(n-2)\right]^{1 / 2}$, where $P_{\mathrm{t}}$ and $P_{0}$ are the measured and calculated quantities of $\mathrm{P}$ released at time $t$, respectively, and $n$ is the number of measurements (Wayne 1989).

The interpretation of the kinetic parameters is as follows. In the simple Elovich model an increasing $\alpha$ and decreasing $\beta$ indicate an increase in desorption rate. The same applies to an increasing and decreasing $b$ in the power function whereby higher doses lead to faster $\mathrm{P}$ desorption (Fekri et al. 2011); $a$ stands for extracted $\mathrm{P}$ and $b$ for the rate of extraction (Siddique and Robinson 2004). Others have similarly interpreted $\mathrm{P}$ release as a function of $\mathrm{P}$ concentration and availability (McDowell and Sharpley 2003). It must be noticed that no systematic attempt has been made in the $\mathrm{P}$ release kinetics literature to interpret the parameters or their simultaneous behavior.

\section{Results}

Physicochemical characteristics of soil, biosolids and vermicompost

The soil was classified as sandy clay loam (ESM Table S1) and bulk density was $1.1 \mathrm{~g} \mathrm{~cm}^{-3}$, a value used to calculate the amendment doses. Soil $\mathrm{pH}$ was acidic. The values of organic matter, total organic carbon, total $\mathrm{P}$, available $\mathrm{P}$, electrical conductivity, and cation exchange capacity were vermicompost $>$ biosolids $>$ soil, whereas soil had higher acidity and available N (ESM Table S1).

$\mathrm{P}$ addition and release

The soil amendments had 27 and 31 times more available P than the soil (vermicompost and biosolids, respectively, ESM Table S1). Once mixed with soil, available $\mathrm{P}$ augmented from $74.8 \mathrm{mg} \mathrm{P} \mathrm{kg}^{-1}$ soil to up to $144 \mathrm{mg} \mathrm{P} \mathrm{kg}^{-1}$ amended soil (ESM Table S1 and 2). In turn, the addition of biosolid and vermicompost increased $\mathrm{P}$ release between 8 and 6 times, respectively. Release presented different empirical patterns: low doses and vermicompost were more linear, denoting a gradual release while concentrations increased dramatically for high doses of biosolids and tended to plateau after 1,000 $\mathrm{h}$ and up until day 65 (Fig. 1). These patterns indicated that $\mathrm{P}$ release responded to the amount of $\mathrm{P}$ added and to amendment type.

In this fast desorbing period (within 360 h or 15 days) $\mathrm{P}$ release ranged between 44 and $62 \%$ responding to biosolid dose (Fig. 1a). In a quite different fashion, release oscillated without a clear trend between 46 and $45 \%$ without clear influence of vermicompost doses (Fig. 1b); this was a lower release than both biosolid and soil alone (49\% in the latter).

The amount of $\mathrm{P}$ released after 1,560 $\mathrm{h}$ (65 days) in the soil control was $5.17 \mathrm{mg} \mathrm{kg}^{-1}$, as compared to $10.47-39.66 \mathrm{mg} \mathrm{kg}^{-1}$ at doses of $18-100 \mathrm{Mg} \mathrm{ha}^{-1}$ in biosolid-amended soil (Fig. 2). In vermicompost-amended
Table 1 Equations used to describe the $\mathrm{P}$ release kinetics (Fekri et al. 2011; Hosseinpur and Pashamokhtari 2008; Shariatmadari et al. 2006)

$P_{\mathrm{o}}: \mathrm{P}$ amount $\left(\mathrm{mg} \mathrm{P} \mathrm{kg}^{-1}\right)$ which can be released at equilibrium

$P_{\mathrm{t}}: \mathrm{P}$ amount (mg $\mathrm{P} \mathrm{kg}{ }^{-1}$ ) released over time $t(\mathrm{~h})$

\begin{tabular}{|c|c|c|}
\hline Model & Kinetic equation & Parameters \\
\hline Zero order & $P_{\mathrm{o}}-P_{\mathrm{t}}=a-k_{\mathrm{o}} t$ & $\begin{array}{l}a \text { : initial desorption rate constant }\left(\mathrm{mg} \mathrm{P} \mathrm{kg}^{-1} \mathrm{~h}^{-1}\right) \\
k_{\mathrm{o}} \text { : zero-order rate constant }\left(\mathrm{h}^{-1}\right)\end{array}$ \\
\hline First order & $\ln P_{\mathrm{t}}=\ln P_{\mathrm{o}}-k_{1} t$ & $k_{1}:$ first-order rate constant $\left(\mathrm{h}^{-1}\right)$ \\
\hline Second order & $1 / P_{\mathrm{t}}=1 / P_{\mathrm{o}}+k_{2}$ & $k_{2}:$ second-order rate constant $\left[\left(\mathrm{mg} \mathrm{P} \mathrm{kg}^{-1}\right)^{-1}\right]$ \\
\hline Simple Elovich & $P_{\mathrm{t}}=1 / \beta \ln (\alpha \beta)+(1 / \beta) \ln t$ & $\begin{array}{l}\alpha \text { : initial desorption rate }\left(\mathrm{mg} \mathrm{P} \mathrm{kg}^{-1} \mathrm{~h}^{-1}\right) \\
\beta \text { : desorption constant }\left[\left(\mathrm{mg} \mathrm{P} \mathrm{kg}^{-1}\right)^{-1}\right]\end{array}$ \\
\hline Power function & $\ln P_{\mathrm{t}}=\ln a+b \ln t$ & $\begin{array}{l}a \text { : initial desorption rate constant }\left(\mathrm{mg} \mathrm{P} \mathrm{kg}^{-1} \mathrm{~h}^{-1}\right) \\
b \text { : desorption rate coefficient }\left[\left(\mathrm{mg} \mathrm{Pg}^{-1}\right)^{-1}\right]\end{array}$ \\
\hline Parabolic diffusion & $P_{\mathrm{t}} / P_{\mathrm{o}}=c+r t^{0.5}$ & $\begin{array}{l}r: \text { diffusion rate constant }\left[\left(\mathrm{mg} \mathrm{P} \mathrm{kg}^{-1}\right)^{-0.5}\right] \\
c: P_{\mathrm{t}} / P_{0} \text { when } r=0 \text { or } t=0 \text { (dimensionless) }\end{array}$ \\
\hline
\end{tabular}


Table 2 Available $\mathrm{P}$ added to the sandy clay loam soil depending on the amendment doses

\begin{tabular}{llcl}
\hline $\begin{array}{l}\text { Amendment } \\
\text { dose } \\
\left(\mathrm{Mg} \mathrm{ha}^{-1}\right. \\
\text { equivalent })\end{array}$ & $\begin{array}{l}\text { Amendment } \\
\text { concentration }(\mathrm{mg} \\
\text { amendment } \mathrm{kg}^{-1} \\
\text { soil) }\end{array}$ & $\begin{array}{l}\text { P added by } \\
\text { biosolid }(\mathrm{mg} \\
\mathrm{P} \mathrm{kg}^{-1} \text { soil) }\end{array}$ & $\begin{array}{l}\text { P added by } \\
\text { vermicompost } \\
\left(\mathrm{mg} \mathrm{P} \mathrm{kg}^{-1}\right. \\
\text { soil) }\end{array}$ \\
\hline $0^{*}$ & 0 & 0 & 0 \\
18 & 5454.5 & 10.88 & 12.75 \\
36 & 10909.0 & 21.76 & 25.09 \\
50 & 15151.5 & 30.21 & 34.84 \\
80 & 24242.4 & 48.36 & 55.75 \\
100 & 30303.0 & 60.45 & 69.69 \\
\hline
\end{tabular}

* Soil control

Table 3 Goodness-of-fit and parameter estimates for $\mathrm{P}$ release kinetics fitted to the desorption data, depending on amendment doses and soil improvers, simple Elovich model

\begin{tabular}{|c|c|c|c|c|c|}
\hline \multirow[t]{3}{*}{$\begin{array}{l}\text { Dose } \\
\left(\mathrm{Mg} \mathrm{ha}^{-1}\right)\end{array}$} & \multirow[t]{3}{*}{ Amendment } & \multirow{2}{*}{\multicolumn{2}{|c|}{$\frac{\text { Goodness-of-fit }}{\text { Simple Elovich }}$}} & \multirow{2}{*}{\multicolumn{2}{|c|}{$\begin{array}{l}\text { Equation parameter } \\
\text { estimates }\end{array}$}} \\
\hline & & & & & \\
\hline & & $r^{2}$ & SE & $\alpha$ & $1 / \beta$ \\
\hline 0 & Soil control & 0.933 & 0.086 & 0.0081 & 0.237 \\
\hline \multirow[t]{2}{*}{18} & Biosolid & 0.903 & 0.096 & 0.0101 & 0.344 \\
\hline & Vermicompost & 0.914 & 0.145 & 0.0101 & 0.344 \\
\hline \multirow[t]{2}{*}{36} & Biosolid & 0.897 & 0.195 & 0.0113 & 0.366 \\
\hline & Vermicompost & 0.911 & 0.156 & 0.0113 & 0.366 \\
\hline \multirow[t]{2}{*}{50} & Biosolid & 0.944 & 0.246 & 0.0123 & 0.537 \\
\hline & Vermicompost & 0.929 & 0.203 & 0.0123 & 0.537 \\
\hline \multirow[t]{2}{*}{80} & Biosolid & 0.937 & 0.415 & 0.0241 & 1.047 \\
\hline & Vermicompost & 0.930 & 0.393 & 0.0246 & 1.047 \\
\hline \multirow[t]{2}{*}{100} & Biosolid & $0.953 *$ & 0.512 & 0.0295 & 1.387 \\
\hline & Vermicompost & 0.899 & 0.635 & 0.0295 & 0.387 \\
\hline
\end{tabular}

$r^{2}>0.95$

$P_{\mathrm{o}}$ : $\mathrm{P}$ amount ( $\mathrm{mg} \mathrm{P} \mathrm{kg}^{-1}$ ) which can be released at equilibrium

$P_{\mathrm{t}}: \mathrm{P}$ amount $\left(\mathrm{mg} \mathrm{P} \mathrm{kg}^{-1}\right)$ released over a time $t(\mathrm{~h})$ soil, final $\mathrm{P}$ release was $7.55-30.79 \mathrm{mg} \mathrm{kg}^{-1}, 15-43 \%$ lower than in biosolids (Fig. 2) even though $\mathrm{P}$ added by biosolids was $15 \%$ lower (Table 2).

$\mathrm{P}$ dose should be lower than $16 \mathrm{mg} \mathrm{kg}^{-1}$ to prevent eutrophication and so the maximum $\mathrm{P}$ amendment dose should be $36 \mathrm{Mg}$ biosolid-amendment $\mathrm{ha}^{-1}$, or $50 \mathrm{Mg}$ vermicompost-amendment $\mathrm{ha}^{-1}$ in which case the $14.27 \mathrm{mg} \mathrm{kg}^{-1} \mathrm{P}$ release would still be lower than the limit.

Kinetic models

$P$ release could not be fitted by zero-, first- or second-order models: their lack of goodness-of-fit was due to non-linearity at short contact times. Conversely, the simple Elovich model adequately showed a linear relationship between $P_{\mathrm{t}}$ (P concentration at a given time $t$ ) and $\ln t$ at $100 \mathrm{Mg} \mathrm{ha}^{-1}$ biosolid amendment (Table 3). In the power function $\ln \mathrm{P}$ and $\ln t$ were linearly related in all treatments except $100 \mathrm{Mg}$ biosolids $\mathrm{ha}^{-1}$ (this treatment had the second lowest $r^{2}$ and highest SE, and its $1 / \beta$ parameter is an outlier in the upward trend of this parameter as doses augment). Finally, the parabolic diffusion law was the best fit considering all treatments (all $r^{2}>0.95$ ). The parameter $r$ (diffusion rate constant) was higher as amendment dose increased. This is consistent with Fig. 2, which shows that higher amendment doses lead to higher final concentration of desorbed P.

From the three most adequate models, $\beta, b$ and $r$ from the simple Elovich, power and parabolic models, respectively, depend on the $\mathrm{P}$ concentration only. $\alpha$ and $a$, from the simple Elovich and power models depend on both $\mathrm{P}$ concentration and time (Table 1). The general behavior of the kinetic parameters mostly responded to amendment: release parameters were higher at higher doses, and soil practically always had the lowest parameters. The simple Elovich and power models behaved as expected: a larger initial desorption rate and lower desorption constant
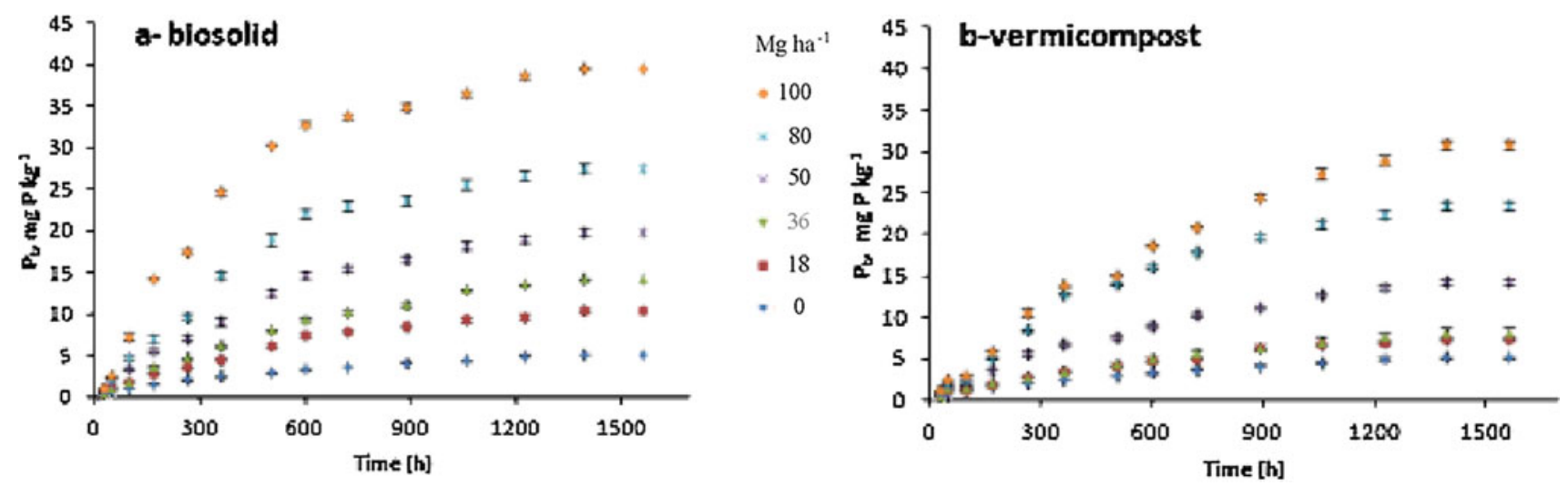

Fig. 1 Cumulative desorbed $\mathrm{P}$ over time in soil amended with biosolid (a) and soil amended with vermicompost (b). Confidence intervals are \pm 1 standard error around the mean 


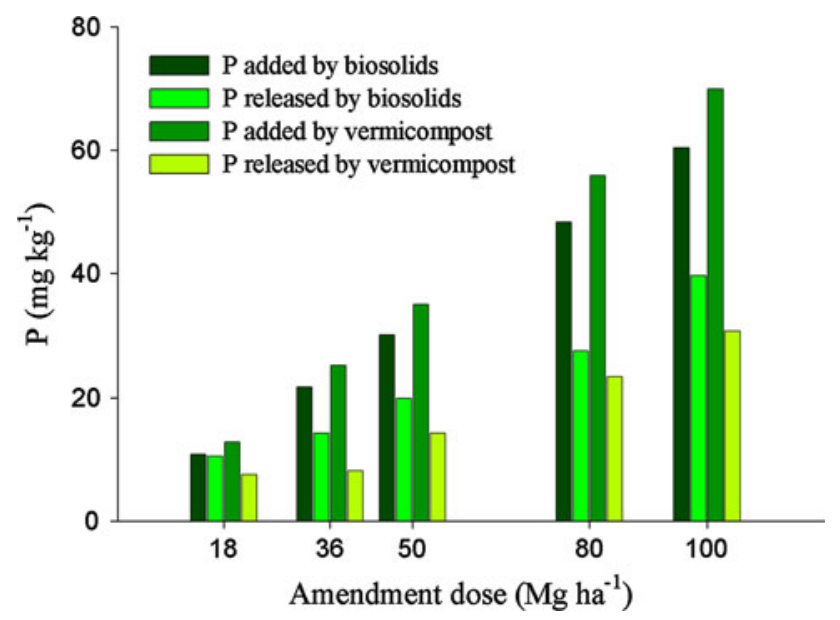

Fig. 2 Added $\mathrm{P}$ and final $\mathrm{P}$ release (after 65 days), in soils amended with biosolids and vermicompost. Eutrophication is likely above $16 \mathrm{mg} \mathrm{P} \mathrm{kg}{ }^{-1}$ (Hosseinpur and Pashamokhtari 2008) and would affect surface water and groundwater (Brenton et al. 2007; Korboulewsky et al. 2002)

augmented release; release also augmented with a higher amendment dose. However, even the parameters expressed in the same units did not yield similar values from one model to the other.

In the simple Elovich, $\alpha$ and $\beta$ could be predicted from one another and responded directly to higher doses in biosolids; neither patterns were observed in vermicompost, though. At all doses but the highest, both amendments showed virtually the same $\alpha$ and $\beta$, highlighting the importance of dose over amendment in this case (Table 3).

In the power function (Table 4; Fig. 3), the parameters were not predictable from either doses or amendment: release augmented at higher doses, but not as predictably as in the simple Elovich model; also, the parameters of the amendments did not resemble each other (suggesting a model sensitive to amendments and doses). Again, biosolids $a$ and $b$ were somewhat predictable from one another (except at the lowest dose), and in this model, $a$ and $b$ could predict each other well in vermicompost.

In the parabolic diffusion model, the release parameters were predictable from each other in vermicompost, not in biosolids. Parameter $c$ is the value of the ratio comparing $\mathrm{P}$ release concentration by time $t$ and final (equilibrium) $\mathrm{P}$ release concentration, when the diffusion rate $r=0$ or $t=0 ; c$ clearly depended on dose in vermicompost and biosolid (except at the latter's highest dose); $r$ directly responded to dose in both amendments, and vermicompost higher doses augmented $\mathrm{P}$ release.

\section{Discussion}

Physicochemical characteristics of soil, biosolids and vermicompost

The $\mathrm{P}$ system is conditioned by $\mathrm{pH}$ and the presence of $\mathrm{Ca}$, $\mathrm{Al}$ and $\mathrm{Fe}$, according to the following equation (Navarro and Navarro 2003):

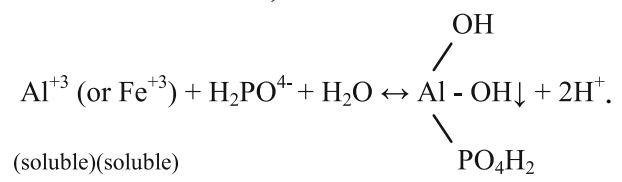

Calcium content was $0.43 \%$ (low as per Navarro and Navarro 2003) and would not interact with $P$ at the acid soil $\mathrm{pH}$ (4.62) found here (Fekri et al. 2011). P bound to $\mathrm{Al}$ and
Table 4 Goodness-of-fit and parameter estimates for $\mathrm{P}$ release kinetics fitted to the desorption data, depending on amendment doses, amendment and fitted function
$* r^{2}>0.95$

$P_{\mathrm{o}}$ : $\mathrm{P}$ amount $\left(\mathrm{mg} \mathrm{P} \mathrm{kg}^{-1}\right)$

which can be released at equilibrium

$P_{\mathrm{t}}: \mathrm{P}$ amount $\left(\mathrm{mg} \mathrm{P} \mathrm{kg}^{-1}\right)$ released over a time $t(\mathrm{~h})$

\begin{tabular}{|c|c|c|c|c|c|c|c|c|c|}
\hline \multirow{3}{*}{$\begin{array}{l}\text { Dose } \\
\left(\mathrm{Mg} \mathrm{ha}^{-1}\right)\end{array}$} & \multirow[t]{3}{*}{ Amendment } & \multicolumn{4}{|c|}{ Goodness-of-fit } & \multicolumn{4}{|c|}{ Equation parameter estimates } \\
\hline & & \multicolumn{2}{|c|}{ Power function } & \multicolumn{2}{|c|}{$\begin{array}{l}\text { Parabolic } \\
\text { diffusion }\end{array}$} & \multicolumn{2}{|c|}{ Power function } & \multicolumn{2}{|c|}{$\begin{array}{l}\text { Parabolic } \\
\text { diffusion }\end{array}$} \\
\hline & & $r^{2}$ & SE & $r^{2}$ & SE & $a$ & B & $c$ & $r$ \\
\hline 0 & Soil control & $0.996^{*}$ & 0.052 & $0.996^{*}$ & 0.022 & 0.0160 & 0.5790 & 0.0414 & 0.0288 \\
\hline \multirow[t]{2}{*}{18} & Biosolid & $0.981 *$ & 0.157 & $0.985^{*}$ & 0.092 & 0.0022 & 0.8360 & 0.1961 & 0.0622 \\
\hline & Vermicompost & $0.985^{*}$ & 0.077 & $0.991 *$ & 0.048 & 0.0171 & 0.6208 & 0.1263 & 0.0435 \\
\hline \multirow[t]{2}{*}{36} & Biosolid & $0.968 *$ & 0.258 & $0.990^{*}$ & 0.103 & 0.0010 & 1.0480 & 0.3824 & 0.0873 \\
\hline & Vermicompost & $0.983^{*}$ & 0.154 & $0.993 *$ & 0.046 & 0.0209 & 0.5995 & 0.1267 & 0.0460 \\
\hline \multirow[t]{2}{*}{50} & Biosolid & 0.942 & 0.316 & $0.979 *$ & 0.207 & 0.0039 & 0.9429 & 0.4078 & 0.1212 \\
\hline & Vermicompost & $0.980 *$ & 0.147 & $0.990^{*}$ & 0.102 & 0.0099 & 0.7535 & 0.2951 & 0.0825 \\
\hline \multirow[t]{2}{*}{80} & Biosolid & $0.954 *$ & 0.258 & $0.959^{*}$ & 0.414 & 0.0106 & 0.8647 & 0.5112 & 0.1704 \\
\hline & Vermicompost & $0.963 *$ & 0.261 & $0.977 *$ & 0.264 & 0.0076 & 0.8946 & 0.5725 & 0.1458 \\
\hline \multirow[t]{2}{*}{100} & Biosolid & 0.898 & 0.450 & $0.995^{*}$ & 0.732 & 0.0182 & 0.8561 & 0.3474 & 0.2384 \\
\hline & Vermicompost & $0.980 *$ & 0.185 & $0.986^{*}$ & 0.265 & 0.0103 & 0.8831 & 0.9776 & 0.1918 \\
\hline
\end{tabular}


Fig. $3 \mathrm{P}$ release data fitted to the different kinetic models
Soil-biosolid
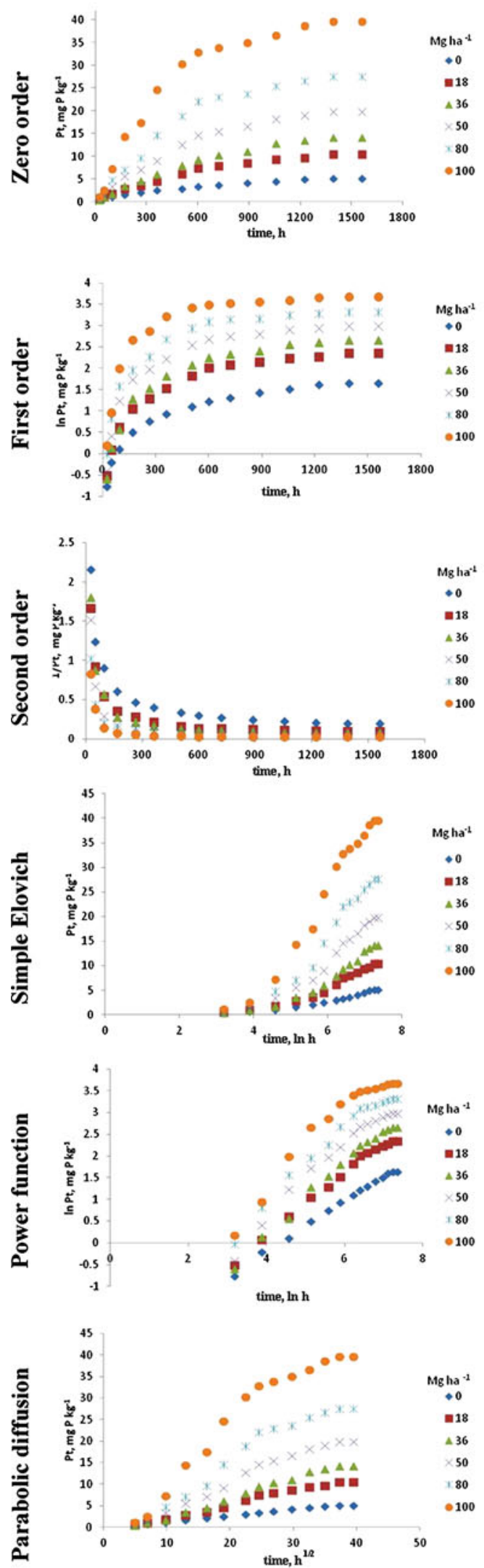

Soil-vermicompost
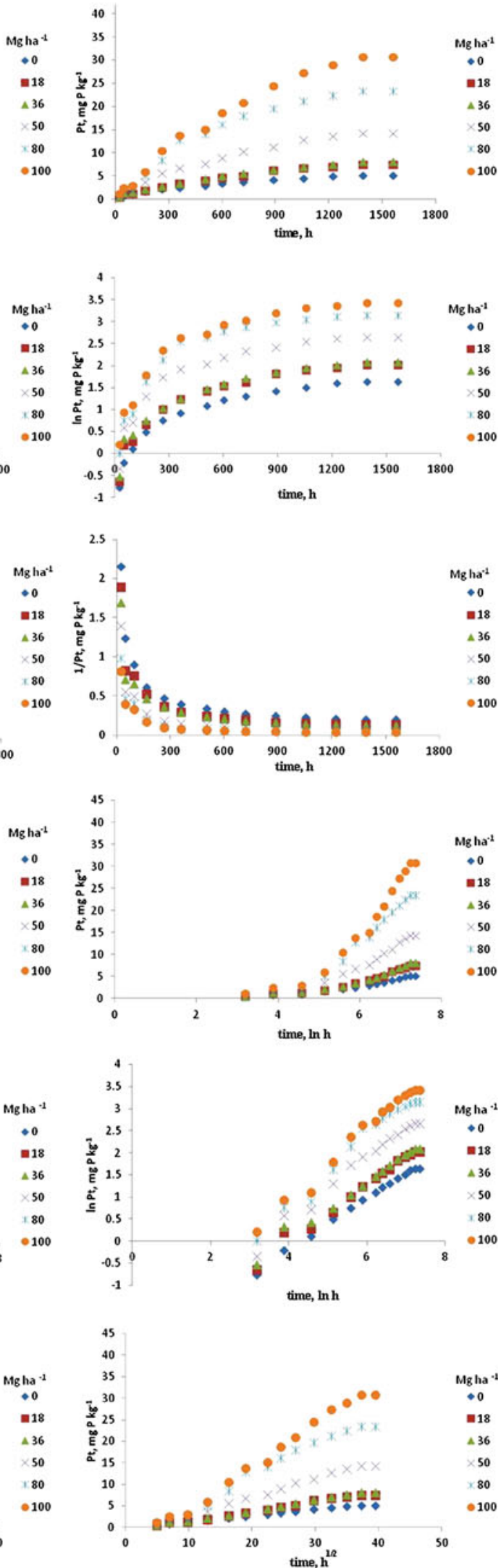

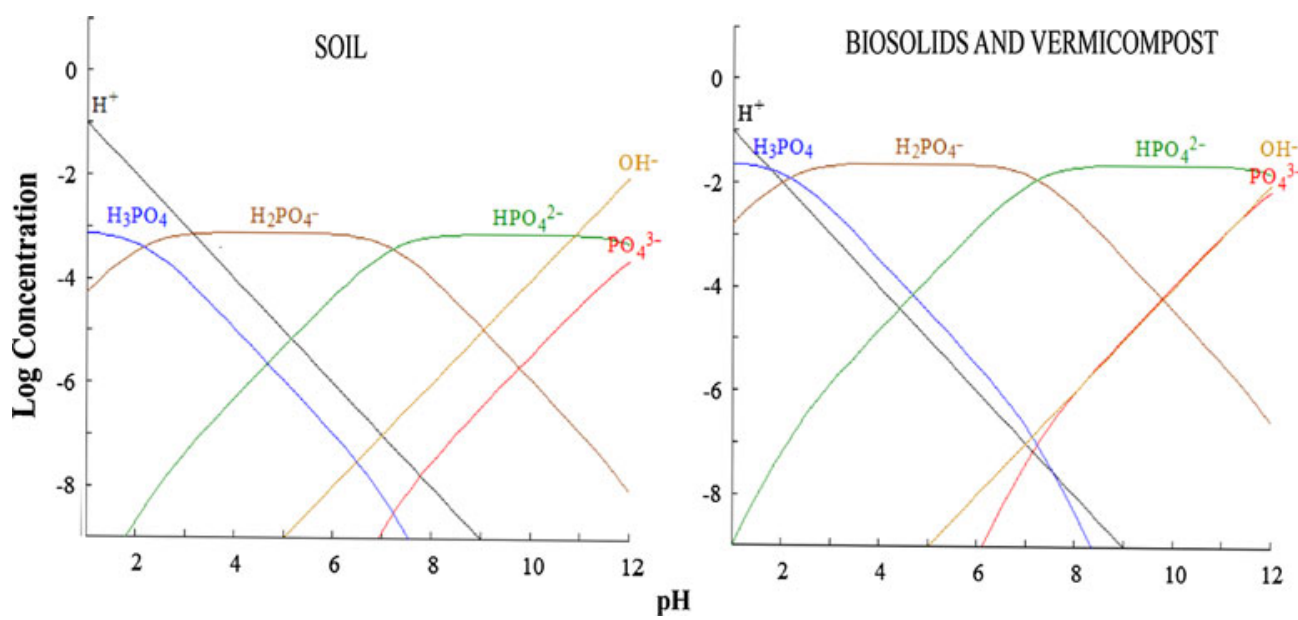

Fig. 4 MEDUSA existence-predominance diagram for $\mathrm{P}$ species (ionic strength $0.01 \mathrm{M} \mathrm{KCl}, 25{ }^{\circ} \mathrm{C}$ ). In soil, a pH of 4.6 pointed to a $\mathrm{H}_{2} \mathrm{PO}_{4}{ }^{-}$predominance and presence of $\mathrm{HPO}_{4}{ }^{2-}$. In slightly acidic

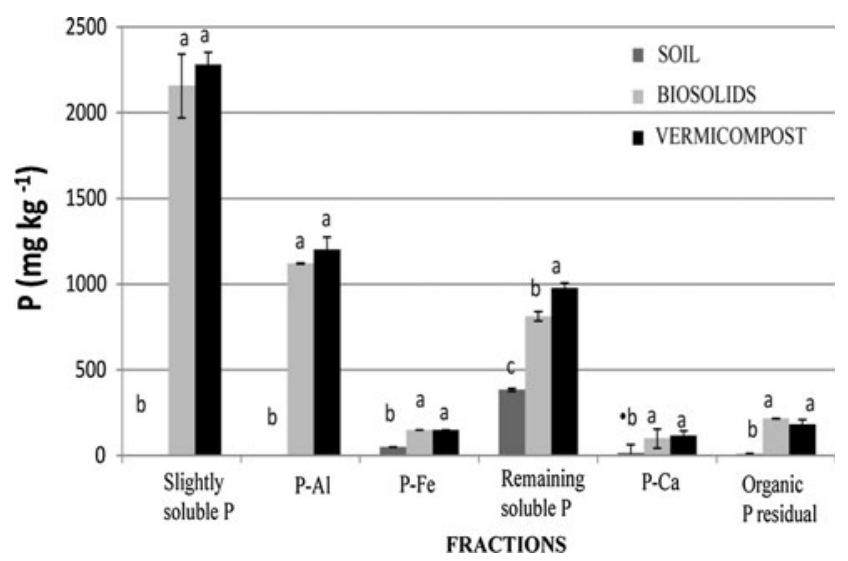

Fig. 5 Fractionation of $\mathrm{P}$ inorganic $\left(\mathrm{mg} \mathrm{kg}^{-1}\right)$ in soil, biosolid and vermicompost. Different letters indicate significant statistical differences $(p<0.05)$. Error bars refer to one standard deviation of the mean

Fe were significantly higher in amendments than soil; these fractions augment $\mathrm{P}$ retention (Lu and O'Connor 2001; Maguire et al. 2001).

Phosphate precipitates in soil were expected from low $\mathrm{pH}$ and $\mathrm{Fe}$ and $\mathrm{Al}$ ions (Fig. 4). Inorganic phosphates are suggested to respond to meteorization and soil maturation: in mature soils-such as the sandy clay loam soil studied herethe occluded phosphates (i.e. the Remaining soluble P fraction) predominate (Fassbender and Bornemisza 1987). Occluded soils have a very limited solubility and $\mathrm{P}$ is seldom available to plants. As to the slightly soluble $\mathrm{P}$ fraction, it was absent in the soil but dominant in biosolids and vermicompost (47.35 and $46.46 \%$, respectively, (Fig. 5). The slightly soluble fraction was a likely factor in $\mathrm{P}$ release.

$\mathrm{P}$ is a scarce resource in the lithosphere but a pollutant in the hydrosphere (Elser and Bennett 2011). The treatments proposed here are geared toward reaching a balance by soils, the predominant solubilized species is $\mathrm{H}_{2} \mathrm{PO}^{4-}$ (Soinne 2009). In biosolids and vermicompost, $\mathrm{H}_{2} \mathrm{PO}_{4}{ }^{-}$still predominated but $\mathrm{HPO}_{4}{ }^{2-}$ increased noticeably

recirculating hydrosphere $\mathrm{P}$ into the soils, especially where available $\mathrm{P}$ is a plant growth limiting factor. Available P: available $\mathrm{N}$ ratios in biosolid and vermicompost were, respectively, 12,000 and 1,000. The accepted explanation is that in Mexico as in other developing countries discharges of phosphates from detergents ending up in sewage sludge are very high (de Haan 1981; Vaca-Paulín et al. 2011). Additionally, $\mathrm{Fe}$ and $\mathrm{Al}$ salts are used as coagulants in wastewater treatments which cause $\mathrm{P}$ to end up in biosolids (Coker and Carlton-Smith 1986; Lee and Lin 2007); this was in particular the case in the wastewater treatment plant under study.

Available P: total P ratios were on average 0.44 and 0.47 in biosolid and vermicompost, respectively. These were values almost thrice that of soil available $\mathrm{P}$ because detergents are a source of inorganic $\mathrm{P}$ in biosolids and vermicomposted biosolids (Fassbender and Bornemisza 1987). Despite this mineral form of $\mathrm{P}$, the vermicompost managed to increase slightly the available $\mathrm{P}$ content, possibly derived from earthworm intestinal transit which helps desorb P from the solid phase material (Jimenez et al. 2003) and bacterial phosphatase activity in vermicompost which largely enhances P mineralization (Garg et al. 2006). However, available P was not significantly different in biosolid and vermicompost, due to very variable domestic detergent discharges as shown in the high standard error of available $\mathrm{P}$ in biosolid.

The higher available $\mathrm{P}$ content in vermicompost was consistent with other reports (Buchanan et al. 1988; Garg et al. 2006). It can be attributed to mineralization by earthworm digestion and its accompanying microorganisms (Capistrán et al. 2004; Liu et al. 2005).

$\mathrm{P}$ addition and release

This $\mathrm{P}$ release assessment used a sandy clay loam soil with $\mathrm{Al}$ and $\mathrm{Fe}$ interactions (Islas-Espinoza et al. 2013). The 
biosolid under study also included $\mathrm{Fe}$ or $\mathrm{Al}$ salts added during wastewater treatment to remove soluble P. This could have lowered $\mathrm{P}$ solubility in the treatments, given the formation of sparingly soluble $\mathrm{Al}-\mathrm{P}$ and $\mathrm{Fe}-\mathrm{P}$ forms, particularly when applied to acidic soils in tropical or highly weathered soils (Sims and Pierzynski 2005).

Even so, $\mathrm{P}$ release with amendments was 6-8 times that of soil alone, similar to a 7.5 times amendment with biosolids with relatively high $\mathrm{P}$ (Hosseinpur and Pashamokhtari 2008) which can be found in organic molecules such as nucleic acids, lipids and inositol polyphosphates (Siddique and Robinson 2003). P release reached $62 \%$ on day 15 (biosolid amendment) similar to $73 \%$ on day 15 with $100 \mathrm{Mg} \mathrm{ha}^{-1}$ biosolid amendment (Hosseinpur and Pashamokhtari 2008 in calcareous soil).

However, the soil amended with biosolids released more $\mathrm{P}$ at a higher rate than vermicompost amendment, even though biosolids added less $\mathrm{P}$ than vermicompost (Figs. 1, 3 ). This is consistent with biosolid P released more readily (Capistrán et al. 2004), which could impair water quality (Penn and Sims 2002), particularly beyond $16 \mathrm{mg} \mathrm{P} \mathrm{kg}^{-1}$ soil (Hosseinpur and Pashamokhtari 2008). The slow $P$ release with vermicompost amendment may help prevent erosion washing or leaching losses of this nutrient.

The probable reasons for slower $\mathrm{P}$ release in vermicompost amendment were threefold. Firstly, it might be attributable to earthworm casts that retain their porosity and structure and contain more water-stable aggregates than surrounding soil, probably due to polysaccharide gums produced by earthworm intestinal bacteria and proliferation of fungal hyphae on the surface of casts. Secondly, phosphatases are produced in the gut of earthworms in response to a need for $\mathrm{P}$ by microorganisms suggesting a $P$ release partly regulated by enzymatic processes (Capistrán et al. 2004; Edwards and Arancon 2005; Tate 1985). Thirdly, vermicompost-amended soils contain more organic matter which enhance nutrient retention, as well as humic acids, fulvic acids and humans which regulate the release of nutrients (Heal et al. 1997; Arancon et al. 2006).

To the best of our knowledge there are no similar studies on $\mathrm{P}$ release in soils amended with vermicomposted biosolids. However, by way of comparison, $\mathrm{P}$ release in temperate soils (UK and New Zealand, McDowell and Sharpley 2003) was 9-55 times faster after 33 days (despite similar available P) than in the soil amended with biosolid and vermicomposted biosolid studied here. However, $\mathrm{P}$ release in (semi)arid soils and biosolid-amended soils at $100 \mathrm{Mg} \mathrm{ha}^{-1}$ doses (Iran, Hosseinpur and Pashamokhtari 2008) were of the same order of magnitude as that resulting from the $36-50 \mathrm{Mg} \mathrm{ha}^{-1}$ maximum doses recommended here (despite lower available P). As to the maximum recommended $36 \mathrm{Mg}$ biosolid amendment ha ${ }^{-1}$ $(\mathrm{d} / \mathrm{w})$ dose, it fell within the $30-60 \mathrm{Mg} \mathrm{ha}^{-1}$ range applied in an uncharacterized temperate soil (Spain, Carbonell et al. 2009). The recommendation was low enough to comply with for instance, the French biosolid authorized limit of $30 \mathrm{Mg} \mathrm{ha}^{-1}\left(10\right.$ year) ${ }^{-1}(\mathrm{~d} / \mathrm{w})$ (Maisonnave et al. 2002). As to the maximum recommended $50 \mathrm{Mg}$ vermicomposted biosolid $\mathrm{ha}^{-1}(\mathrm{~d} / \mathrm{w})$ dose, it was higher than applications which achieved similar $\mathrm{P}$ releases with lower amendment doses: $5 \mathrm{Mg}$ sugar mill vermicompost ha ${ }^{-1}$ clay loam and sandy loam soil (India, Manivannan et al. 2009) and $15 \mathrm{Mg}$ sheep manure vermicompost ha ${ }^{-1}$ loamy soil (Iran, Azarmi et al. 2008). Similar P releases with 3-10 times lower doses could again be attributable to lower $\mathrm{P}$ solubility in the biosolid and soil under study due to reactions with $\mathrm{Al}$ and $\mathrm{Fe}$.

A cautionary note is warranted with regard to the laboratory $\mathrm{P}$ extraction procedures used here and their difference with leachability on the field. The latter is likely to be controlled by soil: water ratio, rate of infiltration, in situ $\mathrm{pH}$, and generally invoked factors influencing $\mathrm{P}$ desorption in soils, including mineralogy, crystallinity, particle size of the mineral, as well as clay, $\mathrm{Al}, \mathrm{Fe}$, carbonate and organic matter contents, and soil solution chemistry $(\mathrm{pH}$, ionic strength, competing anions, oxidation-reduction status, $\mathrm{P}$ species) (Hosseinpur and Pashamokhtari 2008; Sims and Pierzynski 2005).

\section{Kinetic models}

The zero-, first- and second-order models were not adapted to the $\mathrm{P}$ release kinetics in the amended soil. Some such models are suggested to follow at least two first-order kinetics (Shariatmadari et al. 2006 in calcareous soils). In turn, the Elovich simple model (Steffens 1994, in Alfisols with organic fertilizers) and the power equation (McDowell and Sharpley 2003) have been reported as best describing $\mathrm{P}$ release. The results here coincided with the simple Elovich, power function and parabolic diffusion as best $\mathrm{P}$ release models (Shariatmadari et al. 2006) and especially with the parabolic diffusion law as the best fit (Hosseinpur and Pashamokhtari 2008; Shariatmadari et al. 2006).

The simple Elovich and power models behaved as expected: a larger initial desorption rate and lower desorption constant augmented release (Fekri et al. 2011) as amendment dose increased (McDowell and Sharpley 2003). The parabolic diffusion was not expressed in the same manner by all authors cited in Table 1 and this study followed Hosseinpur and Pashamokhtari (2008).

Often the initial fast desorption phase involves labile $\mathrm{P}$, $\mathrm{P}$ bound to reactive surfaces in the aqueous phase, soluble $\mathrm{P}$ from recent amendment, physically adsorbed orthophosphate, and $\mathrm{P}$ complexed by organic matter. Initially rapid reactions correspond to dissolution of poorly 


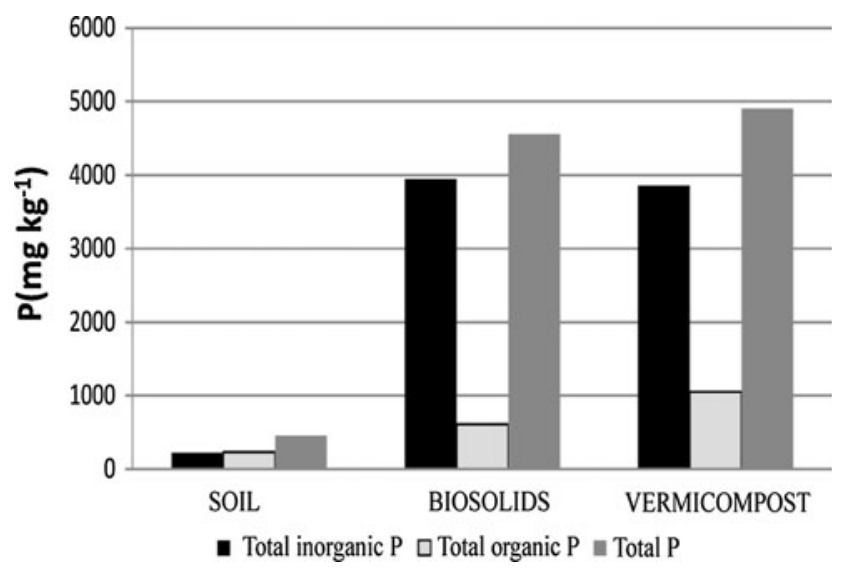

Fig. 6 Organic, inorganic and total $\mathrm{P}\left(\mathrm{mg} \mathrm{kg}^{-1}\right)$ in soil, biosolid and vermicompost

crystalline or amorphous phosphates. Less mobile fractions are proportional to the number of sites occupied by phosphate. Later on, slow $\mathrm{P}$ release most likely originates from diffusion from interior sites inside soil solid phases, aggregates or slow dissolution of amorphous or crystalline solid phases of $\mathrm{P}$. The gradual reduction in $\mathrm{P}$ release rate over time may result from decreasing surface charge and decreasingly interacting adsorbed phosphorus ions (Fekri et al. 2011; Siddique and Robinson 2004; Sims and Pierzynski 2005).

Kinetics are relevant for plant nutrition. Inorganic orthophosphates $\mathrm{H}_{2} \mathrm{PO}_{4}{ }^{-}$and $\mathrm{HPO}_{4}{ }^{2-}$ probably dominated $\mathrm{P}$ forms as a result of low soil $\mathrm{pH}$ (Fig. 4); these inorganic orthophosphates are almost exclusively the $\mathrm{P}$ form absorbed by plants, however, they have to be replenished and easily released (Mozaffari and Sims 1994). More generally, inorganic (more available) $\mathrm{P}$ largely dominated the amendments (Fig. 6). In other biosolid-amended soils, inorganic forms also predominate (Su et al. 2007). The slightly soluble $\mathrm{P}, \mathrm{P}-\mathrm{Al}$ and $\mathrm{P}-\mathrm{Fe}$ fractions of inorganic $\mathrm{P}$ were considerably increased in the amendments (Fig. 5). While slightly soluble $\mathrm{P}$ is the most available to plants (Boschetti et al. 2003; Chang et al. 1983), $\mathrm{P}-\mathrm{Al}$ and $\mathrm{P}-\mathrm{Fe}$ could be responsible for $\mathrm{P}$ retention in amended soil, similar to other conclusions that $\mathrm{Al}$ and $\mathrm{Fe}$ compounds slow down P release (Lu and O'Connor 2001; Maguire et al. 2001). $\mathrm{H}_{2} \mathrm{PO}_{4}{ }^{-}$might also have reacted with hydrous oxides of $\mathrm{Al}$ and $\mathrm{Fe}$ under acidic conditions (Navarro and Navarro 2003).

Innocuity of the amendments seemed fairly reachable: water eutrophication is preventable provided maximum doses, such as those recommended here, are complied with. Unacceptable accumulation of $\mathrm{P}$ in soils amended with manure is common (Nair and Graetz 2002), which is why only $10 \%$ manure was used here and it was composted prior to addition to biosolid for vermicomposting. Finally, earthworms acted as toxicity bioindicators in biosolids (see Sanchez-Hernandez 2006): their survival and reproduction could ensure that plants receive pollutant concentrations below toxic effect threshold.

\section{Conclusions}

Maximum amendment doses were identified for wastewater and solid waste reuse. P release in soil with biosolid and vermicompost was initially rapid and subsequently slowed down, which corresponded to a fast initial and then prolonged fertilizing effect. Low soil $\mathrm{pH}$ facilitated $\mathrm{P}$ bound to aluminum and iron (hence $\mathrm{P}$ retention) and inorganic orthophosphates dominance was probably crucial for plant growth. Similarities were found with kinetics in other soils and amendments in the liberation of $\mathrm{P}$ with respect to time: the parabolic diffusion law seems to be the best fit, suggesting diffusion as a probable limiting step in the liberation of P. Vermicompost added more available P, and released less than biosolids; in addition, earthworms bioindicated that the vermicomposted biosolids were fairly innocuous. The amendments studied here could play a salient role in both $\mathrm{P}$ replenishing and easy release and, within dose limits, avoid contamination to surface and groundwater. The foregoing would assist in the conservation of intensively used sandy clay loam soils.

Acknowledgments The authors wish to thank the Mexican Research Council, CONACyT (Consejo Nacional de Ciencia y Tecnología) for funding the project which led to this publication, as well as the anonymous reviewers. Alejandro de las Heras helped with valuable comments on the content and organization of this paper.

\section{References}

Améndola R, Castillo E, Martínez PA (2005) Perfiles por país del recurso pastura/forraje. México, FAO

Arancon NQ, Edwards CA, Bierman P (2006) Influences of vermicomposts on field strawberries: part 2. Effect on soil microbiological and chemical properties. Bioresour Technol 97:831-840

Azarmi R, Giglou MT, Taleshmikail RD (2008) Influence of vermicompost on soil chemical and physical properties in tomato (Lycopersicum esculentum) field. Afr J Biotechnol 7(14):2397-2401

Boschetti NG, Quintero CE, Benavidez RA, Giuffre L (2003) Cuantificación de las fracciones orgánicas e inorgánicas de fósforo en suelos de la Mesopotamia argentina. Ciencia del Suelo 21:1-7

Bouyoucos GJ (1962) Hydrometer method improved for making particle size analysis of soils. Agron J 54:464-465

Brenton C, Fish E, Mata-González R (2007) Macronutrient and trace element leaching following biosolids application on semi-arid rangeland soils. Arid Land Res Manag 21:143-156

Buchanan MA, Russell E, Block SD (1988) Chemical characteristics and nitrogen mineralization potentials of vermicompost derived 
from different organic wastes. In: Edwards CA, Neuhauser EF (eds) Earthworms in environmental and waste management. SPB Academic Publishing, The Hague, pp 231-240

Capistrán F, Aranda E, Romero J (2004) Manual de reciclaje, compostaje y lombricompostaje. $1^{\mathrm{a}}$ ed. $2^{\mathrm{a}}$ reimpresión. Instituto de Ecología A.C. Xalapa, Ver., México, p 151

Carbonell G, Gómez P, Babín M, Fernández C, Alonso E, Tarazona JV (2009) Sewage sludge applied to agricultural soils: ecotoxicological effects on representative soil organism. Ecotoxicol Environ Safe 72:1309-1319

Cardoso-Vigueros L, Ramírez-Camperos E (2002) Vermicomposting of sewage sludge: a new technology in Mexico. Water Sci Technol 46:153-158

Chang AC, Page AL, Sutherland FH, Grgurevic E (1983) Fractionation of phosphorus in sludge-affected soils. J Environ Qual 12:286-290

Coker EG, Carlton-Smith CH (1986) Phosphorus in sewage sludge as a fertilizer. Waste Manage Res 4:303-319

Contreras-Ramos SM, Escamilla-Silva EM, Dendooven L (2005) Vermicomposting of biosolids with cow dung and oat straw. Biol Fertil Soils 41:190-198

Dayananda D, Giraddi R, Gali K (2008) Effect of salt and sewage water on the survival and reproduction of three earthworm species used in vermicomposting. Karnataka J Agric Sci 21:52-54

de Haan S (1981) Sewage sludge as a phosphate fertilizer. In: Hucker TWG, Catroux G (eds) Phosphorus in sewage sludge and animal waste slurries. D. Reidel Publishing Company, Dordrecht, pp 149-162

Edwards CA, Arancon NQ (2005) Interactions among organic matter, Earthworms and microorganisms in promoting plant growth. In: Magdoff F, Weil RR (eds) Soil organic matter in sustainable agriculture. CRC Press, New York, pp 328-357

Elser J, Bennett E (2011) A broken biogeochemical cycle. Nature 478:29-31

Esteller MV, Martínez-Valdés H, Garrido S, Uribe Q (2009) Nitrate and phosphate leaching in a Phaeozem soil treated with biosolids, composted biosolids and inorganic fertilizers. Waste Manage 29:1936-1944

FAO (2006) Guidelines for soil description. Food and Agriculture Organization of the United Nations, Rome

Fassbender HW, Bornemisza E (1987) Química de suelos con énfasis en suelos de América Latina. Instituto Interamericano de Cooperación para la Agricultura. 2 ed. rev. San José, Costa Rica. Editorial IICA. (Colección de Libros y Materiales Educativos/IICA; no. 81) p 420

Fekri M, Gorgin N, Sadegh L (2011) Phosphorus desorption kinetics in two calcareous soils amended with $\mathrm{P}$ fertilizer and organic matter. Environ Earth Sci. doi:10.1007/s12665-010-0892-9

Franco-Hernández O, McKelligan-Gonzalez N, Lopez-Olguin A, Espinosa-Ceron F, Escamilla-Silvia E, Dendooven L (2003) Dynamics of carbon, nitrogen and phosphorus in soil amended with irradiated, pasteurized and limed biosolids. Bioresource Technol 87:93-102

Garg P, Gupta A, Satya S (2006) Vermicomposting of different types of waste using Eisenia fetida: a comparative study. Bioresour Technol 97:391-395

Gobierno del Estado de México (1996) Planta de Tratamiento de Aguas Residuales. Secretaría de Ecología, Toluca

Gomez-Beltran G (2009) Water and soil effects of biosolid use in agriculture. Unpublished Master's thesis. Esteller MV, supervisor. Interamerican Water Resources Center, Mexico State University, Toluca, $\mathrm{p} 78$

Heal OW, Anderson JM, Swift MJ (1997) Plant litter quality and decomposition: an historical overview. In: Cadisch G, Giller KE (eds) Driven by nature: plant litter quality and decomposition. CAB International, Wallingford, pp 3-30
Hosseinpur A, Pashamokhtari H (2008) Impact of treated sewage sludge application on phosphorus release kinetics in some calcareous soils. Environ Geol 55:1015-1021

Islas-Espinoza M, Esteller MV, Solís-Mejía L, Jiménez-Moleón MC, Ramirez AA (2013) New directions in vermistabilization of sewage sludge. In: Fall C (ed) Advances in water sciences. Plaza y Valdés, Mexico

Jaramillo DF (2002) Introducción a la Ciencia del Suelo. Universidad Nacional de Colombia, Facultad de Ciencias, Medellín

Jimenez J, Cepeda A, Decaëns T, Obserson A, Friesen T (2003) Phosphorus fractions and dynamics in surface earthworm casts under native and improved grassland in a Colombian savanna Oxisol. Soil Biol Biochem 35:715-727

Korboulewsky N, Dupouyet S, Bonin G (2002) Environmental risks of applying sewage sludge compost to vineyards: carbon, heavy metals, nitrogen, and phosphorus accumulation. J Environ Qual 31:1522-1527

Lair JG, Zehetner F, Khan HZ, Gerzabek MH (2009) Phosphorus sorption-desorption in alluvial soils of a young weathering sequence at the Danube river. Geoderma 149:39-44

Lee CC, Lin Shun Dar (eds) (2007) Handbook of environmental engineering calculations. Mc Graw-Hill, NY, pp 1357-1358

Liu X, Hu C, Zhang S (2005) Effects of earthworm activity on fertility and heavy metal bioavailability in sewage sludge. Environ Int 31:874-879

Lu P, O'Connor A (2001) Biosolids effects on phosphorus retention and release in some sandy Florida soils. J Environ Qual 30:1059-1063

Maguire RO, Foy HR, Bailey JS, Sims JT (2001) Estimation of the phosphorus sorption capacity of acidic soils in Ireland. Euro J Soil Sci 52:479-487

Mahimairaja S (2000) Heavy metal accumulation in earthworms. In: Ganesh K (ed) Vermiculture and vermicomposting technology. Department of Environmental Sciences, Tamil Nadu Agricultural University, Coimbatore

Maisonnave V, Montréjaud-Vignoles M, Bonnin C, Revel JC (2002) Impact on crops, plants and soils of metal trace elements transfer and flux, after spreading of fertilizers and biosolids. Water Sci Tech 46:217-224

Manivannan S, Balamurugan M, Parthasarathi, Gunasekaran K, Ranganathan LS (2009) Effect of vermicompost on soil fertility and crop productivity-beans (Phaseolus vulgaris). J Environ Biol 30:275-281

Mariani L, Jiménez JJ, Asakawa N, Thomas RJ, Decaëns T (2007) What happens to earthworm casts in the soil? A field study of carbon and nitrogen dynamics in Neotropical savannahs. Soil Biol Biochem 39:757-767

McDowell RW, Sharpley AN (2003) Phosphorus solubility and release kinetics as a function of soil test $\mathrm{P}$ concentration. Geoderma 112:143-154

Mozaffari PM, Sims JT (1994) Phosphorus availability and sorption in an Atlantic coastal plain watershed dominated by intensive, animal-based agriculture. Soil Sci 157:97-107

Murphy J, Riley J (1962) A modified single solution method for the determination of phosphate in natural waters. Anal Chem Acta 27:31-36

Nair VD, Graetz DA (2002) Phosphorus saturation in Spodosols impacted by manure. J Environ Qual 31:1279-1285

Natchimuthu K, Thilagavathy D (2009) Growth, reproductive biology and life cycle of the vermicomposting earthworm, Perionyx ceylanensis Mich. (Oligochaeta: Megascolecidae). Bioresource Technol 100:4790-4796

Navarro S, Navarro G (2003) Química Agrícola. El Suelo y los Elementos Esenciales para la Vida, 2nd ed. Mundi Prensa, Madrid

NMX-FF-109-SCFI-2007. Humus de lombriz (Lombricomposta) especificaciones y métodos de prueba. Secretaría de Agricultura, 
Ganadería, Desarrollo Rural, Pesca y Alimentación. Diario Oficial de la Federación, México, 25 de febrero de 2003

Olsen SR, Sommers LE (1982) Phosphorus. In: Page AL, Miller RH, Keeney DR (eds) Methods of soil analysis, part 2. Chemical and microbiological properties. ASA, Madison, pp 404-430

Penn JC, Sims JT (2002) Phosphorus forms in biosolids-amended soils and losses in runoff: effects of wastewater treatment process. J Environ Qual 31:1349-1361

Primo YE, Carrasco DJ (1987) Química Agrícola I. Suelos y Fertilizantes. Ed. Alhambra, Madrid

Quesada CA, Lloyd J, Anderson LO, Fyllas NM, Schwarz M, Czimczik CI (2011) Soils of Amazonia with particular reference to the RAINFOR sites. Biogeosciences 8:1415-1440

Rhoades JD (1996) Salinity: electrical conductivity and total dissolved solids. In: Sparks DL (ed) Methods of Soil Analysis. Part 3: Chemical Methods. SSSA Book Series No. 5. SSSA and ASA, Madison, WI, pp 417-435

Rostagno CM, Sosebee RE (2001) Surface application of sewage sludge in the Chihuahuan desert: effects on soils physical properties. Arid Land Res Manag 15:233-244

Sanchez-Hernandez JC (2006) Earthworm biomarkers in ecological risk assessment. Rev Environ Contam Toxicol 188:85-126

Schad P, Haussermann U, Ferber P, Rinneberg K (2001) Phaeozems or ferralsols? low-activity clay soils with mollic horizons in Bolivian tropical lowlands. European Soil Bureau Research Report \#7. Publications of the European Communities, Luxembourg

Shariatmadari H, Shirvani M, Jafari A (2006) Phosphorus release kinetics and availability in calcareous soils of selected arid and semiarid toposequences. Geoderma 132:262-272

Shober A, Sims T (2003) Phosphorus restrictions for land application of biosolids: current status and future trends. J Environ Qual 32:1955-1964

Siddique TM, Robinson SJ (2003) Phosphorus sorption and availability in soils amended with animal manures and sewage sludge. J Environ Qual 32:1114-1121

Siddique TM, Robinson SJ (2004) Differences in phosphorus retention and release in soils amended with animal manures and sewage sludge. Soil Sci Soc Am J 68:1421-1428
Sims JT, Pierzynski GM (2005) Chemistry of phosphorus in soils. In: Tabatabai MA, Sparks DL (eds) Chemical processes in soils. Number 8. Soil Science Society of America Inc. Madison, WI, pp 151-186

Soinne H (2009) Extraction methods in soil phosphorus characterization: limitations and applications. Pro Terra 47. Helsinki University Print, pp 40-49

Solís-Mejía L, Islas-Espinoza M, Esteller MV (2012) Vermicomposting of sewage sludge: earthworm population and agronomic advantages. Compost Sci Util 20:11-17

Song Y, Zhou Q, Xu H, Ren L, Sun T, Gong P (2002) Acute toxicological effects of heavy metal pollution in soils on earthworms. Chinese J Appl Ecol 13(2):187-190

Steffens D (1994) Phosphorus release kinetics and extractable phosphorus after long-term fertilization. Soil Sci Soc Am J 58:1702-1708

Su J, Wang H, Kimberley MO, Beecroft K, Magesan GN, Hu C (2007) Fractionation and mobility of phosphorus in a sand forest soil amended with biosolids. Environ Sci Pollut R 14(7): $529-535$

Tate KR (1985) Soil phosphorus. In: Vaughan D, Malcolm RE (eds) Soil organic matter and biological activity. Kluwer Academic Publishers, Dordrecht, pp 329-377

Thomas GW (1996) Soil pH and soil acidity. In: Sparks DL (ed) Methods of soil analysis. Part 3: Chemical methods. SSSA Book Series No. 5. SSSA and ASA, Madison, WI, pp 475-490

Vaca-Paulín R, Esteller-Alberich MV, Lugo-de la Fuente J, ZabaletaMancera HA (2006) Effect of sewage sludge or compost on the sorption and distribution of copper and cadmium in soil. Waste Manag 26:71-81

Vaca-Paulín R, Lugo J, Martínez R, Esteller MV, Zavaleta H (2011) Effects of sewage sludge and sewage sludge compost amendment on soil properties and Zea mays L. plants (heavy metals, quality and productivity). Rev Int Contam Amb 27(4): 303-311

Wayne WD (1989) Bioestadística, 3rd edn. Limusa, México 